\title{
Exploring the needs of parents for achieving reunification: The views of foster children, birth family and social workers in Spain
}

\author{
Maria Àngels Balsells*, Crescencia Pastor**, Ainoa Mateos**, Eduard Vaquero*, \\ Aida Urrea* \\ *University of Lleida, Department of Pedagogy and Psychology, Lleida, Spain \\ **University of Barcelona, Department of Research Methods and Diagnosis in \\ Education, Barcelona, Spain
}

\author{
Keywords \\ Reunification \\ Child welfare \\ Birth family \\ Social support \\ Family consolidation \\ Content analysis
}

\begin{abstract}
Background: Family reunification refers to the process through which children and adolescents under a measure of temporary separation (foster care or residential) return to live with their biological families. The research has begun to reflect a paradigm change in intervention and support for these families that affects the consolidation of reunification and the prevention of new processes of separation and reentry into the protection system.

Objectives: This article examines the needs of parents who are susceptible to an educational intervention from a positive focus that contributes to the consolidation of family reunification.

Method: Eighteen semi-structured interviews were conducted and 22 discussion groups were convened with 135 participants (63 protection-system professionals, 42 parents and 30 children and adolescents). The data were analyzed through content analysis and were subject to peer revision.

Results: A series of parents' specific educational needs when their children return home was recognized. These needs can be the objects of family intervention based on a positive focus directed toward highlighting parents' strengths and are related to awareness of family progress, emotional management, giving and receiving help from other families and social support. The participants' comments show that feelings of self-sufficiency and positive reinforcement are fundamental for consolidation of the process.

Conclusions: Social support through formal and informal networks may be a path to explore for providing more and better support after returning home. Empowering families so that they can be agents of support for other families can be a way to consolidate reunification, allowing families to be active agents in the reunification process. In addition, listening to children's voices can be a good strategy for family consolidation.
\end{abstract}




\section{Introduction}

There are various alternatives to ensure the welfare of at-risk children and adolescents in Spain. When a child is found in a situation involving maltreatment or negligence, there is the possibility of either remaining with the biological parents (who are then monitored) or being removed. In the latter case, the alternatives are fostering in residential homes, foster care (in kinship or non-kinship families) and adoption. In the first two cases, removal from the family nucleus is expected to be temporary (Balsells et al., 2013). This is when the process of family reunification and work with the biological family begins because, without this intervention, it is very difficult and unlikely that the causes of the separation will disappear and that the children will be able to return home. This process aims to help children and parents to achieve and maintain optimal levels of reconnection and to ensure the stability necessary for children's personal and physical development (Child Welfare League of America, 2002). This aspect is of vital importance because some family-unification processes, after having been formally constituted, cannot stabilize quickly enough, implying that new processes of separation and reentry into the child-protection system may occur (Frame, Berrick, \& Brodowski, 2000). Accordingly, as noted by Delfabbro, Fernandez, McCormick, and Kettler (2013), family reunification or restoration is a well-established area of international research.

Statistics related to failed reunification and reentry into the protection system vary by country (Kimberlin, Anthony, \& Austin, 2009). In the United Kingdom, tracking for 2 years after reunification shows reentry figures of 47\% (Farmer \& Wijedasa, 2013), whereas 5-year tracking increases the percentage of reentries to 65\% (Lutman \& Farmer, 2013).

However, American studies indicate that $19-50 \%$ of reunified children return to the protection system after two or three years (Barth, Weigensberg, Fisher, Fetrow, \& Green, 2008; Biehal, 2006). Wulczyn (2004), in a study conducted in the United States of 1.3 million children from 12 states, shows that although failed reunifications are declining, $25 \%$ of cases that begin to reunify reenter the protection system within one year. To minimize these cases and to achieve stable reunification, various authors note the importance of working with families at the moment of reunification (Balsells et al., 2013; Barth et al., 2008; Brook, McDonald, \& Yan, 2012; Canali et al., 2001; Kimberlin et al., 2009; Lutman \& Farmer, 2013).

In Spain, according to the official 2012 data, there are a total of 39,754 open cases of children under government protection. The rate corresponds to 479 measures per hundred thousand children and represents a reduction from the previous year (Ministerio de Sanidad y Política Social. Observatorio de la Infancia, 2014). Unlike other countries, in Spain, residential care is used in $75 \%$ of placement cases and is the primary resource for children who are placed in out-of-home care.

Another particular characteristic of Spain is the predominance of kinship foster care among foster care cases: kinship foster care is provided in $85 \%$ of family placement cases (Palacios \& Jiménez, 2009). However, the absence of unified data from the official statistics in Spain concerning the number of children who return to their biological family is evident. The data are lacking because each autonomous community is responsible for recording the information. Consequently, little research on this topic exists. 


\section{Perspectives on working with families for reunification}

The research is beginning to reflect a paradigm change in intervention in and support for families at social risk (Amorós et al., 2009; Canali et al., 2001; Rodrigo, Cabrera, MartínQuintana, \& Máiquez, 2009; Rodrigo, Máiquez, et al., 2009) that enables a positive focus for family intervention, potentiating the parents' strengths rather than simply attempting to eliminate their deficits (Bravo \& Del Valle, 2009; Del Valle, López, Montserrat, \& Bravo, 2009; Milani, Serbati, Ius, Di Masi, \& Zanon, 2013; Proctor et al., 2011; Walsh, 2002). As Osterling and Han (2011) and Ayala-Nunes, Jiménez, Hidalgo, and Jesus (2014) have shown, empowerment is seen as a relevant factor for parents to be able to assume their responsibilities. The Child Welfare Information Gateway (2011) recommends empowering these families through training programs on the part of children's protective services, including at the moment of reunification.

European social policies that are more recent have also echoed this new focus. Recommendation 19 of the European Council (Consejo de Europa, 2006), which relates to policies of support for positive parenting, asks for recognition of the importance that parents develop competencies in positive parenting and for provision of the support necessary for parents to fulfill their responsibilities in the upbringing of their children. In Spain, Organic Law 1/1996 of January 15 for Judicial Protection of the Minor (Gobierno de España, 1996), the National Strategic Plan for Childhood and Adolescence 2013/2016 (Ministerio de Sanidad Servicios Sociales e Igualdad, 2013) and the Committee on the Rights of the Child of the United Nations in its observational report for Spain (Comite de los Derechos del Niño, 2010) also promote the revaluing of the biological family and protective interventions for children that support family preservation and reunification. Among other measures, the law and reports foresee providing parents with sufficient support mechanisms to fulfill their responsibilities in raising their children and prioritizing the family itself for a process of reunification.

In the area of family reunification, this new focus is beginning to generate results and to highlight new keys for family intervention to consolidate reunification and prevent reentry. Consolidation arrives when family living has been reestablished and a natural equilibrium of relations has been achieved. Analysis of the research allows the identification of some aspects where an intervention with families based on this newfocusmay have an important role in consolidation.

First, according to the approach of Lietz and Strength (2011), a process of family reunification implies that the parents have a clear awareness of the progress that has allowed the children to return home. This means, on the one hand, that families recognize the changes that have made reunification possible and, on the other, that they have feelings of positive reinforcement for these changes (i.e., they have a positive view of the situation). Accordingly, Osterling and Han (2011) discuss not only families' perseverance through the course of the process as a factor in consolidating reunification but also selfevaluation and personal determination to preserve achievements once reunification has occurred. Thus, following the analysis of Rodrigo and Byrne (2011) regarding factors that develop positive parenting, potentiating certain of these factors, such as levels of internal control and self-sufficiency, contributes to families acquiring a greater awareness not only of their progress but also that factors in making progress partially depend on their own performance. 
Second, emotional management of families' feelings at the moment of reunification has also been noted to be a necessity particular to this phase. On the one hand, parents feel happiness about being together again, but on the other hand, they feel uncertainty and fear about a new phase and the possibility of a new separation (Jiménez, Martínez, \& Mata, 2010). In the early days at home, there is often a phase of idyllic and harmonious time together, a "honeymoon", which over time is affected by day-to-day problems, occasionally leading to situations of crisis and stress. In this sense, Lin and Ensel (1989) find it indispensable for families to have available and be able to maintain the instrumental and expressive resources that help them to manage day-to-day situations.

For this reason, it is important for parents to be prepared, to know these phases and to know that they have tools sufficient to manage their emotions (Bravo \& Del Valle, 2009; Del Valle \& Fuertes, 2007).

According to Lietz and Strength (2011), the meaning that families give to their experiences strengthens them and allows them to trust in themselves. Thus, they must transform their initial fears and see their experience as positive, as an opportunity to improve their situation.

Trusting in themselves and recognizing individual worth and that of the rest of the family members add a feeling of identity to the family and help to preserve family unity because the family strives to remain together (Del Valle, Bravo, \& López, 2009; Del Valle \& Fuertes, 2007; Osterling \& Han, 2011; Thomas, Chenot, \& Reifel, 2005).

Third, some authors (Berrick, Cohen, \& Anthony, 2011; OECD, 2012; Serbati \&Milani, 2012) note that empowerment of families can occur by connecting already consolidated and reunified families with recently reunified families. This type of relationship prevents the feeling of isolation and solitary experience suffered by some biological families.

This is a matter of providing social and emotional support to families, standing up for their voices with respect to protection services, helping connect families with formal and informal networks, and helping families to advocate for themselves (Frame, Conley, \& Berrick, 2006; Leake, Longworth-Reed, Williams, \& Potter, 2012; Lorthridge, McCroskey, Pecora, Chambers, \& Fatemi, 2012; Nilsen, Affronti, \& Coombes, 2009).

Additionally, empowering families that have consolidated a reunification process to be support agents can help give positive meaning to their process of struggle (Leake et al., 2012). Lietz and Strength (2011) also note that the final phase of family resilience in the process of reunification is to help, using their experience, other families passing through the same situation of adversity. Likewise, Whitelaw (1997) has already noted that transforming families into support families is based on two basic principles: (1) the empowering and potentiation of the family and (2) the ecological perspective based on Bronfenbrenner's ecological model.

Finally, the support of formal and informal networks is a necessity that most influences families in at-risk situations (Byrne, Rodrigo, \& Martín, 2012; Rodrigo, Martín, Máiquez, \& Rodríguez, 2007; Sala-Roca, Villalba, Jariot, \& Arnau, 2012). In consolidating processes of reunification, parents and children need to feel that, after returning home, they are accompanied by professionals and/or people close by. Various authors consider support in this phase to be fundamental (Farmer \& Wijedasa, 2013; Lutman \& Farmer, 2013).Maluccio (2000) emphasizes that informal support needs to be considered 
indispensable to the reunification process. Thomas et al. (2005) emphasize the importance of support arising out of negative impacts that may pose a risk for family stability, especially for the children. The Child Welfare Information Gateway (2011) recommends tracking after returning home and training programs on the part of children's protection services as key elements in the formal network.

\section{Current study}

In summary, our literature review provides elements to consider as the focus of intervention for families directed toward the consolidation of reunification. This article presents the results of an investigation with the goal of examining, using the voices of the protagonists, the needs of parents who are susceptible to a positive family intervention that contributes to the consolidation of family reunification.

\section{Methods}

\subsection{Research design}

This study is qualitative, with descriptive-explicative goals. It included an exploratory design using discussion groups and semi-structured interviews with multiple informants: professionals from children's protection services and parents, children and adolescents involved in processes of family reunification. This multi-informant character of the study allowed for the discovery of relevant aspects as seen from various perspectives.

\subsection{Sample and sampling procedures}

This study drew on a total of 135 participants. Sixty-three were professionals who worked in the children's protection services, 42 were parents either recently reunified or with plans for reunification and 30 were children or adolescents who had passed through a process of either family or residential care.

Selection criteria for the professionals were as follows: (1) working in the children's protection system; (2) experience in residential or family care; and (3) representative of the multi-disciplinary nature of the professionals, that is, of various areas of training, including social educators, pedagogues, psychologists and social workers.

Selection criteria for the parents were as follows: (1) families who were already reunified or were waiting to be reunified in the next one or two months; (2) families that had undergone or were undergoing a reunification plan; (3) families with the predisposition and desire to collaborate with professionals; and (4) families with various characteristics related to age, family structure, etc.

For the children, the criteriawere as follows: (1) age between 11 and 21 years old and related to the biological families selected; (2) time spent in foster care of at least one year; and (3) no physical, mental or sensory incapacity.

The characteristics of the professionals, the parents, and the children and adolescents participating are presented in Tables 1, 2 and 3, respectively. 


\begin{tabular}{|c|c|}
\hline Characteristics & Professionals $(\mathrm{N}=63)$ \\
\hline \multicolumn{2}{|l|}{ Gender } \\
\hline Women & $47(74.60 \%)$ \\
\hline Men & $16(25.40 \%)$ \\
\hline \multicolumn{2}{|l|}{ Age } \\
\hline $25-35$ & $16(25.80 \%)$ \\
\hline $36-45$ & $29(45.16 \%)$ \\
\hline Over 46 & $18(29.04 \%)$ \\
\hline \multicolumn{2}{|l|}{ Training } \\
\hline Social educators & $20(31.75 \%)$ \\
\hline Pedagogues & $10(15.87 \%)$ \\
\hline Psychologists & $20(31.75 \%)$ \\
\hline Social workers & $13(20.63 \%)$ \\
\hline \multicolumn{2}{|l|}{ Intervention type } \\
\hline Biological family & $37(58.73 \%)$ \\
\hline Residential care & $16(25.40 \%)$ \\
\hline Family care & $10(15.87 \%)$ \\
\hline \multicolumn{2}{|c|}{ Table 2 Characteristics of the participating parents } \\
\hline Characteristics & Parents $(\mathrm{N}=42)$ \\
\hline \multicolumn{2}{|l|}{ Gender } \\
\hline Women & $32(76.19 \%)$ \\
\hline Men & $10(23.81 \%)$ \\
\hline \multicolumn{2}{|l|}{ Family situation } \\
\hline Reunified & $37(88.09 \%)$ \\
\hline Undergoing reunification & $5(11.91 \%)$ \\
\hline \multicolumn{2}{|l|}{ Family structure } \\
\hline Parents together & $18(42.86 \%)$ \\
\hline Parents separated / Divorced & $19(45.24 \%)$ \\
\hline One-parent family / Widower & $05(11.90 \%)$ \\
\hline \multicolumn{2}{|c|}{ Table 3 Characteristics of the participating children and adolescents } \\
\hline Characteristics & Children and adolescents $(\mathrm{N}=30)$ \\
\hline \multicolumn{2}{|l|}{ Gender } \\
\hline Girls & $16(53.33 \%)$ \\
\hline Boys & $14(46.67 \%)$ \\
\hline \multicolumn{2}{|l|}{ Age } \\
\hline $11-14$ & $13(43.33 \%)$ \\
\hline $15-17$ & $9(30.00 \%)$ \\
\hline Over 18 & $8(26.67 \%)$ \\
\hline \multicolumn{2}{|l|}{ Family situation } \\
\hline Reunified & $21(70.00 \%)$ \\
\hline Undergoing reunification & $9(30.00 \%)$ \\
\hline \multicolumn{2}{|l|}{ Measure } \\
\hline Kinship foster care & $8(26.67 \%)$ \\
\hline Residential care & $17(56.67 \%)$ \\
\hline Multiple measure & $5(16.66 \%)$ \\
\hline
\end{tabular}

\subsection{Measures and instrumentation}

To collect the data, discussion groups and semi-structured interviews were used. Eighteen interviewswere conducted (16with adolescents and 2 with parents), and 22 discussion groups were convened ( 9 with professionals, 8 with parents and 5 with children).

The two techniques (focus groups and interviews) used for data collection facilitated access to participants because, in the cases in which there were not enough people to hold a discussion group, interviews were conducted instead. However, in the case of adolescents, the technique chosen at the outset was the interview, thus avoiding differences in age and maturity and providing a space where they could express themselves in confidence and free from peer pressure. The number of participants in each discussion group varied between 3 and 8 participants. The numerical data are shown in Table 4. 
$\underline{\text { Table } 4 \text { Procedures and their participants }}$

\begin{tabular}{cccc}
\hline Procedure & Professionals & Parents & Children and adolescents \\
\hline $\begin{array}{l}\text { Focus Group (N) } \\
\text { Average number of }\end{array}$ & 9 & 8 & 5 \\
$\begin{array}{l}\text { participants in the focus } \\
\text { group }\end{array}$ & 7 & 5 & 3 \\
\hline \begin{tabular}{l} 
Interviews (N) \\
\hline
\end{tabular} & - & 2 & 16 \\
\hline
\end{tabular}

A script was prepared that included the following instruments: (1) an identification form for collecting basic data on the participants; (2) a script with questions for developing the discussion groups or semi-structured interviews; and (3) a summary form in which the investigators were to collect aspects related to the development of the groups, such as the date, duration and place of realization, the participants' motivations, group cohesion and dynamics and, based on the responses of the interviewees, whether the questions were appropriate for the objectives.

The scripts were prepared as a result of the research review on the subject in which key elements to be investigated were detected. The questions were the same for both the discussion groups and the semi-structured interviews. They may be consulted in Table 5 . The focus of the questions sought to provide opportunities for participants to present their experiences in processes of reunification: how it occurred, what their feelings were, what assistance they received, etc., from the perspectives of the parents, the children and the professionals involved.

\subsection{Procedures}

To ensure exactness of information, all the interviews and discussion groups were audio recorded and transcribed. Two investigators from the team went to each child protection service with which contact was maintained. One investigator had the role of motivator, and the other was in charge of recording and confirming that the criteria established in the instructions were followed.

The content analysis was performed using the bottom-up system or system of coding guided by data (Gibbs, 2012). The first stage of analysis was textual, selecting paragraphs, fragments and important quotes from transcripts of the interviews and discussion groups. The second stage was conceptual, to identify the categories and subcategories that may have been interrelated. These were defined when the data reached saturation. For processing qualitative data, the program Atlas.ti 6.2 was used.

As a result of the dialog between the theory and the data collected, the following categories were established: (1) awareness of family progress; (2) emotional management; (3) giving and receiving aid from other families; and (4) social support. These categories were the same for each of the informants, with the purpose of triangulating the data and thus, as Gibbs (2012) notes, obtaining a more precise view of the object of study. 
Table 5 Question scripts for the 3 informants and their relation to the dimensions of analysis

\begin{tabular}{llll} 
D.1 & D.2 & D. 3 & D. 4 \\
\hline
\end{tabular}

\section{Professionals}

1 What support and what work are typically carried out when minors have returned home to the biological family? What support do you believe biological families and children need during the first moments of reunification?

2 Which professional interventions led to good results, and which did not?

3 Would you like to add any comment that might facilitate identifying needs that favor the reunification of families? Is there some other evaluation that you believe should be incorporated into work with biological families, host families, professionals from centers, and hosted minors so that reunification is successful?

\section{$\begin{array}{llll}X & X & X & X\end{array}$}

\section{Parents}

1 During this phase, what support or assistance from professionals was most useful to you? What support or assistance do you think was lacking?

2 What would you emphasize from this particular moment in order for your child's return home to occur in a satisfactory way (assistance, informal and formal support, training, etc.)?

3 In general, what helped your families to get ahead and deal with the difficulties that presented themselves? How do you believe your family was able to successfully achieve the child's return home? What would you most emphasize? Is there something else that $\begin{array}{llll}X & X & X & X\end{array}$ you would like to explain?

\section{Children and adolescents}

1 At the moment of reunification, do you believe it is necessary to receive some training or support so that living together works better? Do you believe your parents needed or need some type of help at this moment?

2 If you had to make a recommendation to other people who find themselves dealing $\begin{array}{llllllllll}\text { with this situation, how would you advise them? What would you tell professionals? } & X & X & X & X\end{array}$ Families? Children?

In the scripts for the discussion groups and the semi-structured interviews, the language of the questions was adapted to the contexts and the participants. The data were peer reviewed to maintain the reliability and credibility of the data. Thus, if there were some discrepancies in the selection of a word, it was reviewed, and an agreement was reached regarding which words would be culturally appropriate in context.

The process of extracting codes and categories was evaluated by various judges. Thus, similar to the content analysis, it was subjected to peer review to achieve the maximum reliability and credibility of the data extracted. 


\subsection{Ethical considerations}

To develop the investigation, ethical considerations were taken into account. A document to provide informed consent was prepared so that participants would understand the study and could grant their authorization.

The document explained the goal of the study, the scientific purpose, the individuals' rights as participants and the confidentiality of the data collected. Before the interviews were done, they were encouraged to ask any question or to ask for any clarification to assist with their understanding and desire to participate. Similarly, the fact that they had the right to refuse to answer any question was emphasized. In the case of the children, it was fundamental to ask for the authorization and consent of either the parents or of the public administration that held legal guardianship.

\section{Results}

\subsection{Awareness of family progress}

The results show that families are aware of changes and achievements realized through the process. They note progress in the development of parental competencies, along with changes related to the contextual aspects that favor a more stable environment for the children. With respect to parental competencies, they note that they learned a great deal and mention changes related to the establishment and supervision of educational plans, skills in assertive communication, educational co-responsibility, recognition and satisfaction with the parental role, capacity for self-evaluation and family leisure time together. Likewise, contextual aspects appear, such as better organization of household tasks and more work stability.

"I have reconsidered, I have seen my flaws, and I have corrected them
quite a bit. I say, look, I am working hard at work, I am more focused
on my son, I have shared more things with him, and I spend more
time..."
Parents' focus group

However, program awareness is not always valued as a consequence of family effort; occasionally, there are families that are less aware and do not value their leading role in the changes produced, attributing them to external factors, such as religion, fate, or even forgetting what happened:

"He is back home, and it is like absolutely nothing happened." Parents' focus group

Conversely, the interviewees argue for the need for more training to become aware of their children's developmental changes. The results indicate that awareness of family progress is closely related to developmental changes that the child has undergone during care. Parental competencies must adapt to the real evolutionary moment of the child returning home, along with the new customs and routines that the child has adopted in the foster family or in residential care. The need for parents to be aware of these changes is fundamental to consolidate reunification. 
"Preparation [is important] because you leave them at seven years old and when they give them back to you at age fourteen, you think that they are still seven."

Parents' focus group

\subsection{Emotional management}

The results show that although there are feelings of happiness and responsibility, feelings related to insecurity and fear predominate. The family has been separated for a period, and the parents feel insecure because they see their children as strangers with whom they will have to learn to live.

"Families have to learn to live with their child once again. Sometimes, he is a stranger: they do not recognize him after several years of being away from the house, it produces insecurity for them."

Parents' focus group

Insecurity accompanies the fear that parents feel, especially at the beginning. There are various reasons for this fear: concern that the children will return to foster care, fear of the changes of adolescence, fear of not having work, fear of not knowing how to act, fear of the children's reaction and fear of repeating earlier patterns. Some participating professionals do not consider such insecurities to be negative.

On the contrary, they can be a good sign that indicates that parents are not idealizing the return home and that they are afraid of making the same errors as in past. Thus, fear does not have to be a bad sign but instead a question that should be addressed:

"They should also understand that you already have this, that it is part of the process, that having fear is a good sign, above all in cases in which a moment of euphoria means that you are not paying attention and can fall into past errors."

Professionals' focus group

The discourses of the study participants note that managing their emotions can take place in specific spaces where such emotions can be expressed after reunification-i.e., meeting points with professionals - to share feelings and experiences and to learn to manage emotions that appear in the course of this new situation of reencountering their children. Therapeutic support, where parents can relax and establish a climate of expression, also appears as a strategy for managing these emotions:

"And we are with you because look at how we have stretched a single question, because
this is the psychological support that they did not give us... And why they didn't give
more to us? We could talk for hours and hours. This is why we needed to talk, to get it off
of our chests - and now that you ask me, I am going to want to stay and talk and talk."

Parents' focus group

\subsection{Helping other families}

Content analysis enabled identification of the important role that is beginning to be played by the strategy of support from families that have passed through similar situations. Most 
of those interviewed comment that they would like to participate in group activities that would allow them to spend time with other families. "I think that there should be a place for, like... or maybe, like now, talking...
because whether you like it or not, hearing other people also helps you because...
like you did... because it can also help you to know how you could behave on
other occasions. And some type of professional, that also [would be helpful]."
Parents' focus group
"Or some place, so that you could see how to treat a child, how you shouldn't treat
them, and how you can treat your child so that you are not too soft with the child."

Parents' focus group

Professionals agree, noting the need for space in common with other people, preferably people who have experienced the same situation, who can give advice and explain what to expect. Furthermore, professionals believe that such a space would be interesting not only during reunification but also during the entire process.

"I think that they are very defenseless, so that if someone who is going through the same thing, or who has gone through the same thing could talk, it would be interesting."

Professionals' focus group

"Cases in which the return has been relatively successful, involving families that can explain to other families who are at this point how they did it, what they found, what fears they had... It would be helpful in preventing anxiety about the return. At best, it would be better than talking with us as professionals."

Professionals' focus group

This idea gains even more support when the parents interviewed offer positive evaluations of meeting with other families and commenting on their situation, as they did in the discussion groups established for this study. Parents comment that thanks to those meetings, they have learned from other families and have a space for expressing themselves to people who understand them.

"Although the situation with my daughter is practically settled, it is still good to chat and hear others' opinions, and likewise, you realize certain things; that you are not the only one to whom things happen. Then, you say, 'and if she failed in this, it could be that I am failing at something."

Parents' focus group

Finally, professionals and parents believe that they should create more resources for reunified families, in which such families can participate and have support.

\footnotetext{
"You would have to look for spaces where the parents could participate, like before the open centers, where the parents could be involved and be supported during the early days."

Professionals' focus group
}

\subsection{Social support after returning home}

Once a family has been reunified, continuity of assistance requires parents and children to continue thinking of professionals as a source of support. However, Spain's childprotection system does not stipulate either a tracking time or supervision after returning home. According to professionals, the tendency is to see reunification as an end, as a closure. 
"We should see reunification as a continuity, not as a period and separation. The current tendency is [to see it as] a rupture."

Professionals' focus group

This lack of a protocol for tracking after returning home by specialized services generates various situations and attitudes. The results show that there are families who perceive a lack of professional support and experience feelings of loneliness after having been intensively tracked during the entire process of recovering their children:

"You feel like you are losing them, you know?

Like, you feel alone. What do I do now?" Parents' focus group

Conversely, other families perceive this lack of support as a test because they must solve problems by themselves.

\footnotetext{
"It's already a lot. I think they gave us a lot of help and I can't ask for more. I always say, I think we all must learn how to solve our problems."

Parents' focus group
}

Finally, a third attitude emerges regarding social support during this phase. This attitude is related to a fear of the child protection service's control function. Parents' discourse shows how they associate asking for social support as proof of incompetence that could lead to new separation and loss of their children to state care. They fear using social services because they believe that social services personnel will believe that they are doing badly and that their children will be taken away again.

"In my case, I don't dare to talk with the assistant and tell her to come and help me because I know that for her I have nothing to offer them, and they will take them from me, as far as she is concerned."

Parents' focus group

However, professionals interpret the fact that parents continue to see professionals as a source of help as a positive indicator that the parents are aware of their own difficulties. Furthermore, professionals believe that parents feel safer, calmer, better looked after and supported if they continue with assistance, once reunified, which will prevent the failure of the reunification.

\footnotetext{
"The fact that it is so progressive is for this reason: so that the parents don't disconnect, they continue coming, consulting the professionals... and we attempt to ensure that the return is supported at every point and that the parents can take on responsibilities. We delegate more and more to the parents, which increases security for the parents with respect to their duties and obligations, while at the same time the children feel more looked after, supported, and safer." Professionals' focus group
}

The support that professionals offer at these moments is focused on resolving doubts and problems that arise, working on false beliefs, working on fears and preventing the errors of the past. In some cases, professionals also provide material aid.

"Yes, we are still in touch with the people from the center. They are helping us a lot: if we need something, they give it to us."

Girl, 17 years old 


\section{Discussion}

This study provides the perspective of all who are involved in the important subject of the consolidation of the reunification process. The views of parents, children and professionals contribute to broadening our knowledge of the phenomenon and coincide with noting which aspects of working with families can be addressed through a more positive focus to help with consolidation. The study has allowed us to localize and narrow the specificity of parents' particular needs that contribute to reducing reentry and that are amenable to working with families based on this focus.

We emphasize that the awareness of family progress is relevant to consolidating reunification, which means that it is important for families to have made changes over the course of the reunification process (Lietz \& Strength, 2011) and to realize that these changes were due to their own efforts. From an ecological perspective, development of parenting has to do with the following: (1) childhood needs; (2) parental competencies; and (3) interaction with the psychosocial context (Drake, Jonson-Reid, \& Sapokaite, 2006; Fisher, Burraston, \& Pears, 2005; Milani et al., 2013; Rodrigo, Máiquez, \& MartínQuintana, 2010).

The results of this study indicate how families in the stage of consolidation clearly recognize their progress relative to two of these areas: (1) competencies and (2) context. However, previous studies have noted the importance of all family members being aware of the changes produced on the following three levels (Balsells et al., 2013): (1) the child's need to be aware of how the situation has improved for his health, his education, his emotional stability and his self-esteem; (2) parental competencies, recognizing the changes stemming from the acquisition of skills necessary for a proper parental role with respect to the children and their proper care; and (3) the context, identifying the changes related to a more stable environment for increasing the income level, making modifications to the home or incorporating social supports into family functioning, among others.

Accordingly, the needs of the parents at this stage that emerge from this analysis are related to a greater awareness and identification of the three levels at which parents can observe their progress from the moment a measure of temporary protection was taken until the moment at which family reunification has taken place. It is important to focus work with families so that they can manage to recognize their achievements at these levels.

However, awareness of changes made and family progress involves going beyond an objective view. In other words, it is important to know not only that changes have been made that justify the reunification but also that the people who comprise the family nucleus should feel proud of their achievements, recognizing their personal merits and those of the other members of the family. This self-reinforcement and reinforcement of others, along with the feeling of family identity, are protective factors for the families in the sense that they help to preserve family unity because when a family feels that it is a family, it works harder to stay together. Moreover, Lietz and Strength (2011) identify as a principal strength the recognition and reinforcement that families feel with respect to changes they have succeeded in implementing. 
The participants' reports showed how the process of re-establishing family living involves moments of reflection that are sometimes very positive and other times negative, until a natural equilibrium of intrafamily relations is achieved. This allowed us to corroborate that feelings of self-sufficiency and positive reinforcement are fundamental for consolidating the process, but this is not always achieved. This finding has an important implication for practice, given that intervention with these families will tend to focus on improvement and consolidation of that perception. Therefore, one deduces that another parental necessity consists of stimulating self-sufficiency, greater internal control and awareness, competencies noted by Rodrigo and Byrne (2011) as necessary for exercising parenting in a positive form in contexts of risk and high risk. On the basis of the model of positive family intervention, one can help parents feel not only that they play a central role but also that they are active and able to improve the perception of self-sufficiency (Byrne et al., 2012; Máiquez, Rodrigo, Capote, \& Vermaes, 2000; Rodrigo, Cabrera, et al., 2009).

Conversely, results showed that despite the fears that these families have in various phases of the reunification process, support from other families that have gone through the same situations helps them manage their emotions. Accordingly, the presence of these fears, insecurities and uncertainties can be noted and the need for intervention highlighted to provide parents with the tools for managing their emotions in this phase of the reunification process (Bravo \& Del Valle, 2009; Del Valle \& Fuertes, 2007). Some authors note that people passing through situations of risk attribute positive value to receiving support from other people who are experiencing or who have experienced the same situation (Bernedo, Salas, Fuentes, \& García-Martín, 2014; Milani et al., 2013). For families who are in this process, feeling supported by others prevents feelings of solitude, frustration, incomprehension and isolation. Furthermore, such families are able to identify with real examples of overcoming the situation, which stimulates their motivation to change the adverse situations that surround them (Balsells et al., 2013).

It is important to note that the consolidation of the reunification process and securing awareness of progress can be seen as reinforced when these families move to providing support to other families. According to the suggestions of Lietz and Strength (2011), the final phase of a process of family resilience in cases of reunification arrives when these families are able to "give social support" to other families who are living in similar situations. For these families, it is helpful to promote their family strengths by feeling useful through assisting other families and feeling comforted by having overcome the situation.

Participation in this type of process can serve as a factor protecting against reentry, assisting in the development of professional skills and promoting socio-emotional wellbeing, such as self-confidence and self-efficiency (Leake et al., 2012). With the necessary support, these families can move from recipients of assistance to transmitters of resources (Serbati \&Milani, 2012) and to active agents in their reunification processes.

In addition, there is a clear need to change the perception that reunification means a closing or a rupture depending on the view of the participants. These same families acknowledge the need for parents and children to be supported not only by professionals from both inside and outside the protection system but also in the informal network. 
At the formal level, the implications for child protection professionals are clear. After reunification, families must be provided with the formal resources necessary for reunification to continue over time. At the informal level, the complexity of establishing and maintaining a good network of social relations with friends, family members, neighbors, etc. and of finding families that have experienced similar family situations underlines two other important implications. There is a need for these same families to have the ability to play a new role supporting other families that are in different phases of separation-reunification. These implications coincide with fundamental aspects in this phase of the reunification process (as noted by various authors) (Farmer \&Wijedasa, 2013; Lutman \& Farmer, 2013) because they can prevent episodes of reentry into the protection system.

\section{Conclusions}

This article has shown that parents have a series of specific needs after their children have returned home, which can be the object of a family intervention based on a positive focus directed at potentiating the parents' strengths. Accordingly, sharing the necessary relationship between formal and informal networks to provide more and better support after returning home could be a path worth exploring.

First, we wish to highlight the development of groups of fathers and mothers who are experiencing a reunification process. These groups can provide (in the first instance) an opportunity for child-protection professionals to follow up and to perform socioeducational work. The objectives of this work can be directed in a focused manner toward the necessities detected to include strengthening parents' parenting abilities, their awareness of progress and their emotional management of everything that is involved in having children return to the home. Additionally, these groups can be a space for strengthening families' formal and informal network, sharing experiences and spaces with people who are experiencing a similar situation.

A second noteworthy point is to highlight the possibilities that support families can offer based on a relationship of trust due to their shared experiences of having passed through similar processes. Empowering families so that they can be agents of support for other families has also been suggested as a way to consolidate reunification, allowing families to participate as active agents in the reunification process and in the processes of other families that are or will be undergoing similar processes. In this sense, establishing an informal and less structured and hierarchical connection between families provides a double benefit. On the one hand, it can inspire hope and optimism through the example of someone who has passed through a similar situation. On the other hand, it provides support to the families. Participation in this type of process can serve as a protection factor given that it increases the supporting family's self-confidence and self-sufficiency. For families that have already passed through situations of adversity, acting as a supporting family helps them promote their family strengths, gives meaning to their family history, helps them to feel useful through helping other families and comforts them because they have overcome the situation.

Finally, it is important to emphasize that one of the limitations that we have found in the study was the small contribution obtained from the children's participation. The voice of the children in the interventions (as in studies concerning their rights and welfare) is found 
in the methodology that we have suggested for investigating processes of family reunification. There is scant scientific literature in this field that includes children's voices, and for that reason, children's voices were a priority of this investigation. Thus, children were accounted for and incorporated as participants in the methodological design.

However, the content analysis of the data shows that their contribution level was low. Children find it difficult to discuss their experiences, reporting little data with respect to the information requested of them. This may be caused, in part, by the meager tradition in our context of experiments that include children. This has meant that the results obtained from children regarding their parents' needs in the process of family consolidation have been scant. In this sense, despite the difficulties found in obtaining children's views, the investigation of alternative methods of collecting information is both a continuing challenge and one of our research team's goals for the immediate future.

The fact that children have a voice in investigations that analyze processes inwhich they are an active part contributes to the triangulation of information sources and to the promotion of processes of child participation. Only children can tell us, in a way that is faithful to their reality, how they felt and lived the process of family reunification. For that reason, children cannot remain at the margin, even though we did not quantitatively obtain the results expected.

Another limitation of the study was access to families. The system of child protection works with families at different stages, but there are few that are in the final stage of the process, in which the return home will occur soon or took place a few months earlier. In addition, we must factor in the desire of the families to participate. Participation means reliving a process that is painful for them, and not all families are ready to do this. These circumstances mean that the study had a limited group of families and children and adolescents. Nevertheless, during data analysis, regarding the contributions from both the groups of parents and the groups of children and adolescents, saturation of data was achieved. That is, the data and existing categories were repeatedly confirmed and did not seem to contain new ideas (Gibbs, 2012). Thus, some personal nuance may have been lost, but this does not influence the final results, given that we were less interested in the opinion of a particular person than in the elements that were key to the successful reunification of the families.

\section{Acknowledgments}

This study has been developed by the investigation group GRISIJ (Research Group in Social-educational Child Intervention) and financed by the Spanish Ministry of Science and Innovation (EDU2011-00144- C02-01), the Department of Universities, Research and Information Society of the Government of Catalonia (2009SGR 1392). 


\section{References}

Amorós, P., Pastor, C., Balsells, M. À., Fuentes-Peláez, N., Molina, M. C., \& Mateos, A. (2009). Family resilience and quality of life in family crisis situation. In $I V$ International Forum Resilience Regulation Qualité de vie. Louvain-la-Neuve, Belgique.

Ayala-Nunes, L., Jiménez, L., Hidalgo, V., \& Jesus, S. (2014). Family feedback in Child Welfare Services: A systematic review of measures. Children and Youth Services Review, 44, 299-306. doi:10.1016/j.childyouth.2014.07.004

Balsells, M. À., Pastor, C., Molina, M. C., Fuentes-Peláez, N., Vaquero, E., \& Mundet, A. (2013). Child Welfare and Successful Reunification: Understanding of the Family Difficulties during the Socio-Educative Process. Revista de Cercetare Si Interventie Sociala, 42, 228-247.

Barth, R. P., Weigensberg, E. C., Fisher, P. A., Fetrow, B., \& Green, R. L. (2008). Reentry of elementary aged children following reunification from foster care. Children and Youth Services Review, 30, 353-364. doi:10.1016/j.childyouth.2007.10.002

Bernedo, I. M., Salas, M. D., Fuentes, M. J., \& García-Martín, M. Á. (2014). Foster children's behavior problems and impulsivity in the family and school context. Children and Youth Services Review, 42, 43-49. doi:10.1016/j.childyouth.2014.03.022

Berrick, J. D., Cohen, E., \& Anthony, E. K. (2011). Partnering with Parents: Promising Approaches to Improve Reunification Outcomes for Children in Foster Care. Journal of Family Strengths, 11(1, article 14), 1-13.

Biehal, N. (2006). Reuniting looked-after children with their families: A research review. York.

Bravo, A., \& F. Del Valle, J. (2009). Crisis y revisión del acogimiento residencial. Su papel en la protección infantil. Papeles Del Psicólogo, 30(1), 42-52.

Brook, J., McDonald, T. P., \& Yan, Y. (2012). An analysis of the impact of the Strengthening Families Program on family reunification in child welfare. Children and Youth Services Review, 34, 691-695. doi:10.1016/j.childyouth.2011.12.018

Byrne, S., Rodrigo, M. J., \& Martín, J. C. (2012). Influence of form and timing of social support on parental outcomes of a child-maltreatment prevention program. Children and Youth Services Review, 34(12), 2495-2503. doi:10.1016/j.childyouth.2012.09.016

Canali, C., Colombo, D. A., Maluccio, A. N., Milani, P., Pine, B. A., \& Warsh, R. (2001). Figli e genitori di nuovo insieme. La riunificazione familiare (Vol. Documentaz). Padova: Fondazione "Emanuela Zancan."

Child Welfare Information Gateway. (2011). Family Reunification: What the Evidence Shows. Washington. 
Child Welfare League of America. (2002). Family Reunification. Washington.

Comité de los Derechos del Niño. (2010). Examen de los informes presentados por los Estados partes en virtud del artículo 44 de la Convención. Observaciones finales: España (CRC/C/ESP/CO/3-4) (Vol. 46329). Ginebra, Suiza.

Consejo de Europa. Recomendación Rec 19 del Comité de Ministros a los Estados Miembros sobre políticas de apoyo a la parentalidad positiva (2006). Europe.

Del Valle, J. F., Bravo, A., \& López, M. (2009). El acogimiento familiar en España: implantación y retos actuales. Papeles Del Psicólogo, 30(1), 33-41.

Del Valle, J. F., \& Fuertes, J. (2007). El acogimiento residencial en la protección a la infancia. Madrid: Pirámide.

Del Valle, J. F., López, M., Montserrat, C., \& Bravo, A. (2009). Twenty years of foster care in Spain: Profiles, patterns and outcomes. Children and Youth Services Review, 31, 847-853. doi:10.1016/j.childyouth.2009.03.007

Delfabbro, P., Fernandez, E., McCormick, J., \& Kettler, L. (2013). Reunification in a complete entry cohort: A longitudinal study of children entering out-of-home care in Tasmania, Australia. Children and Youth Services Review, 35, 1592-1600. doi:10.1016/j.childyouth.2013.06.012

Drake, B., Jonson-Reid, M., \& Sapokaite, L. (2006). Re-reporting of child maltreatment: does participation in other public sector services moderate the likelihood of a second maltreatment report? Child Abuse \& Neglect, 30(11), 1201-1226. doi:10.1016/j.chiabu.2006.05.008

Farmer, E., \& Wijedasa, D. (2013). The Reunification of Looked After Children with Their Parents: What Contributes to Return Stability? British Journal of Social Work, 43, 1611-1629. doi:10.1093/bjsw/bcs066

Fisher, P. A., Burraston, B., \& Pears, K. (2005). The early intervention foster care program: permanent placement outcomes from a randomized trial. Child Maltreatment, 10(1), 61-71. doi:10.1177/1077559504271561

Frame, L., Berrick, J. D., \& Brodowski, M. L. (2000). Understanding reentry to out-ofhome care for reunified infants. Child Welfare, 79(4), 339-369.

Frame, L., Conley, A., \& Berrick, J. D. (2006). "The Real Work is What They Do Together": Peer Support and Birth Parent Change. Families in Society: The Journal of Contemporary Social Services, 87(4), 509-520. doi:10.1606/1044-3894.3566

Gibbs, G. (2012). El análisis de datos cualitativos en Investigación Cualitativa. Madrid: Ediciones Morata.

Gobierno de España. Ley Orgánica 1/1996, de 15 de enero, de Protecció Jurídica del Menor, de modificación parcial del Código Civil y de la Ley de Enjuiciamiento Civil. , Pub. L. No. 15 (1996). España: BOE. 
Jiménez, J., Martínez, R., \& Mata, E. (2010). Guía para trabajar la historia de vida con niños y niñas. Acogimiento familiar y residencial. Sevilla: Junta de Andalucía.

Kimberlin, S. E., Anthony, E., \& Austin, M. J. (2009). Re-entering foster care: Trends, evidence, and implications. Children and Youth Services Review, 31, 471-481. doi:10.1016/j.childyouth.2008.10.003

Leake, R., Longworth-Reed, L., Williams, N., \& Potter, C. (2012). Exploring the Benefits of a Parent Partner Mentoring Program in Child Welfare. Journal of Family Strengths, 12(1, Article 6), 1-24.

Lietz, C. A., \& Strength, M. (2011). Stories of Successful Reunification: A Narrative Study of Family Resilience in Child Welfare. Families in Society: The Journal of Contemporary Social Services, 92(2), 203-210. doi:10.1606/1044-3894.4102

Lin, N., \& Ensel, W. (1989). Life stress and health: Stressors and resources. American Sociological Review, 54, 382-399.

Lorthridge, J., McCroskey, J., Pecora, P. J., Chambers, R., \& Fatemi, M. (2012). Strategies for improving child welfare services for families of color: First findings of a community-based initiative in Los Angeles. Children and Youth Services Review, 34, 281-288. doi:10.1016/j.childyouth.2011.10.025

Lutman, E., \& Farmer, E. (2013). What Contributes to Outcomes for Neglected Children Who Are Reunified with Their Parents? Findings from a Five-Year Follow-Up Study. British Journal of Social Work, 43, 559-578. doi:10.1093/bjsw/bcr184

Máiquez, M. L., Rodrigo, M. J., Capote, C., \& Vermaes, I. (2000). Aprender en la vida cotidiana. Un programa experiencial para padres. Madrid: Visor.

Maluccio, A. N. (2000). What works in family reunification. In What works in Child Welfare (pp. 163-171). Washington, DC: Child Welfare League of America.

Milani, P., Serbati, S., Ius, M., Di Masi, D., \& Zanon, O. (2013). Programma di Intervento Per la Prevenzione dell'Istituzionalizzazione. Padova: Università degli Studi di Padova.

Ministerio de Sanidad Servicios Sociales e Igualdad. (2013). II Plan estratégico nacional de infancia y adolescencia 2013-2016 (II PENIA) (Vol. 2016). Madrid.

Ministerio de Sanidad y Política Social. Observatorio de la Infancia. (2014). Boletín de Datos Estadísticos de Medidas de Protección a la Infancia (Datos 2012). Madrid.

Nilsen, W., Affronti, M., \& Coombes, M. (2009). Veteran Parents in Child Protective Services: Theory and Implementation. Family Relations, 58(December), 520-535.

OECD. (2012). Starting Strong III. A quality toolbox for early childhood education and care. OECD Publishing. doi:dx.doi.org/10.1787/9789264123564-en 
Osterling, K. L., \& Han, M. (2011). Reunification outcomes among Mexican immigrant families in the child welfare system. Children and Youth Services Review, 33, 16581666. doi:10.1016/j.childyouth.2011.04.020

Palacios, J., \& Jiménez, J. (2009). Kinship Foster Care: Protection or Risk. Adoption \& Fostering, 33(3), 64-75.

Proctor, L. J., Van-Dusen, K., Litrownik, A. J., Newton, R. R., Davis, I. P., \& Villodas, M. (2011). Factors associated with caregiver stability in permanent placements: a classification tree approach. Child Abuse \& Neglect, 35, 425-436. doi:10.1016/j.chiabu.2011.02.002

Rodrigo, M. J., \& Byrne, S. (2011). Social Support and Personal Agency in At-Risk Mothers. Psychosocial Intervention, 20(1), 13-24. doi:10.5093/in2011v20n1a2

Rodrigo, M. J., Cabrera, E., Martín-Quintana, J. C., \& Máiquez, M. L. (2009). Las competencias parentales en contextos de riesgo psicosocial. Intervención Psicosocial, 18(2), 113-120.

Rodrigo, M. J., Máiquez, M. L., Byrne, S., Rodríguez-Ruiz, B., Martín-Quintana, J. C., Rodríguez-Suárez, G., ... Rodriguez-Ruiz, B. (2009). Crecer felices en familia. Programa de apoyo psicoeducativo para promover el desarrollo infantil. Valladolid: Junta de Castilla y León.

Rodrigo, M. J., Máiquez, M. L., \& Martín-Quintana, J. C. (2010). Parentalidad positiva y políticas locales de apoyo a las familias. Orientaciones para favorecer el ejercicio de las responsabilidades parentales desde las corporaciones locales. Madrid: Ministerio de Sanidad y Política Social.

Rodrigo, M. J., Martín, J. C., Máiquez, M. L., \& Rodríguez, G. (2007). Informal and formal supports and maternal child-rearing practices in at-risk and non at-risk psychosocial contexts. Children and Youth Services Review, 29(3), 329-347. doi:10.1016/j.childyouth.2006.03.010

Sala-Roca, J., Villalba, A., Jariot, M., \& Arnau, L. (2012). Socialization process and social support networks of out-of-care youngsters. Children and Youth Services Review, 34(5), 1015-1023. doi:10.1016/j.childyouth.2012.02.002

Serbati, S., \& Milani, P. (2012). La genitorialità vulnerabile e la recuperabilità dei genitori. Minorigiustizia, 3, 111-119.

Thomas, M., Chenot, D., \& Reifel, B. (2005). A Resilience-Based Model of Reunification and Reentry: Implications for Out-of-Home Care Services. Families in Society: The Journal of Contemporary Social Services, 86(2), 235-243.

Walsh, F. (2002). A family resilience framework: Innovative practice applications. Family Relations, 51, 130-137.

Whitelaw, S. (1997). Parenting Pioneers and Parenting Teams: Strengthening Extended Family Ties in Family Support. Journal of Family Strengths, 2(1, Article 6), 1-14. 
Wulczyn, F. (2004). Family Reunification. The Future of Children, 14(1), 95-113. doi:10.2307/1602756 